\title{
Arguments based on biocultural diversity to cease abandonment of traditional agricultural systems: Lessons from Poland
}

\author{
Barbara Prus $^{1}$ (D) Michał Uruszczak ${ }^{1}$ (iD $\cdot$ Józef Hernik $^{1}$ (D)
}

Received: 17 June 2021 / Revised: 31 August 2021 / Accepted: 15 September 2021 /

Published online: 22 September 2021

(C) The Author(s) 2021

\begin{abstract}
The Polish rural cultural landscape is inherently linked to a special, centuries-old system that combines agricultural tradition and biodiversity. One of such environmentally, ecologically, agriculturally, historically, and culturally unique areas is the Kraków-Częstochowa Upland. Home to small agricultural holdings, this diversified mosaic is where agricultural, husbandry, craft, and local industry experience is handed down the generational chain. Developmental changes and progress are becoming the gravest threats to the area. The purpose of the paper is to assess traditional agricultural systems in the Lesser Poland part of the Kraków-Częstochowa Upland considering landscape features, agricultural biodiversity, food and livelihood security, traditional local knowledge systems, cultural values-in particular, systems of values - and social organisations that promote them. The research shows that biodiversity is entwined with cultural diversity. The vanishing of agricultural systems due to changed socio-economic conditions and environmental overprotection is a serious threat to the biological and cultural diversity in the upland. The authors employed a SWOT analysis - a tool that can investigate interactions and determine the best development strategy - to identify relationships between cultural and biological diversity.
\end{abstract}

Communicated by Mauro Agnoletti.

Barbara Prus

barbara.prus@urk.edu.pl

Michał Uruszczak

michal.uruszczak@urk.edu.pl

Józef Hernik

jozef.hernik@cyf-ker.edu.pl

1 Department of Land Management and Landscape Architecture, Faculty of Environmental Engineering and Land Surveying, University of Agriculture in Krakow, ul. Balicka 253c, 30-149 Kraków, Poland 


\section{Introduction}

The European landscape is for the most part of cultural origin. Agricultural, forestry, and pastoral practices are inherent in it (Grove and Rackham 2001). The practices can be active or abandoned, but the type of environment they create is always shaped by cultural factors. Every culture moulds its surroundings just as the environment affects how cultures evolve. It is a bilateral feedback loop between culture and the environment. Many ways of how people have shaped the natural landscape over centuries have yielded one of the most representative examples of diversity of cultural identities in the Old World (Pitte 1994). Biological and cultural diversity is a recent field of research, but it was not until the late 1990s that researchers started to investigate biocultural diversity. In light of the above, the Florence Declaration of 2014, focusing on biocultural diversity is highly appreciated (Agnoletti and Rotherham 2015).

European rural landscapes had remained virtually unchanged until the Second World War. They have often adapted to socio-economic changes while retaining features of their identity. Changes in the landscape are directly related to the land use structure. According to statistical data, Poland was dominated by agricultural land $(67.2 \%$ of the country territory), 53.9\% of which was arable land and over $13.0 \%$ meadows and pastures in 1950. Forests occupied nearly $22.0 \%$ of the area of Poland. Over $11.0 \%$ were settlement and transport land, mining areas and water (Poławski 2009). The first years after the Second World War focused on a scheme to integrate the territory, restore the damaged economy and transport network, and change the share of manufacturing and agriculture in the economy's structure. About 1200 new factories were planned with several hundred situated in less developed areas (Węcławowicz 2002). The next stage of industrialisation ranged from 1955 to 1970 and focused on industrial areas. Their development was funded on largescale, primarily industrial projects, auxiliary structures, and housing stock. The Kraków region and Częstochowa region were much strengthened. Industrialisation and urbanisation led to a clear land use change and permanent changes in land use structure, resulting in a gradual increase in developed, industrial, commercial, and transport areas, followed by mines, workings, and construction sites. Urbanised and industrialised land use types spread mainly into arable land, meadows, and pastures. The dominant trend was the conversion of arable land into developed or industrial areas. Forests were affected as well. New industrial and urbanised areas have changed the local land use practically permanently. Simultaneously, a series of guidelines for afforestation was established by the Chief Commission for Afforestation and Tree Planting of the Central Spatial Planning Agency of 1946 in Poland after the Second World War. The optimum forest cover standard was assumed to be $28.0 \%$ of the total territory of Poland. Afforestation should be carried out first on wasteland and then on the poorest soils. Afforestation that followed resulted in land use changes. They involved increase forest areas and conversion of arable land, meadows, and pastures into forests.

Following the second half of the 20th century, traditional landscapes underwent dynamic changes, with some lost (Macdonald et al. 2020). The current socio-economic trends contribute to agricultural land abandonment, industrialisation, and environmental protection policy and additionally support and promote renaturalisation. They threaten critical cultural heritage assets. Although it is difficult to change these trends, cultural heritage strategies require more attention (Agnoletti 2014). Regrettably, these agricultural systems are under the constant pressure of such factors as climate change, increased competition for natural resources, and socio-economic changes both in Europe 
and globally (Agnoletti et al. 2019). The changes are further exacerbated in Central and Eastern Europe by consequences of the socio-economic transformation of 1989. These areas undergo adverse migration due to the low economic viability of farming and small family business. It results in the recent abandonment of traditional farming and foodprocessing practices and loss of endemic species and breeds. Historic agricultural and food processing systems have always been the foundation for modern and future innovations and agricultural and food technologies. The cultural, environmental, and agricultural diversity of these unique agricultural systems is still visible in many parts of the globe.

GIAHS is a living and evolving system of human communities keeping in touch with their territory represented by a cultural and agricultural landscape. People living in changing conditions adapted to the potential and limitations posed by the environment, mainly those resulting from climate change, and shaped the landscape and environment to various degrees (Kohsaka et al. 2019). This has led to the accumulation of experience over generations and widening and deepening of knowledge, and complex and diverse actions taken to preserve precious cultural values. The abundance and range of knowledge and expertise on managing natural resources ensured decades of food and livelihood security, reducing the risk related to ongoing political and systemic changes. The resilience of agricultural systems depends on their ability to adapt to new challenges while retaining the biological and cultural wealth and production capabilities. It requires constant agroecological and social innovations combined with a careful transfer of generations worth of knowledge and experience. Any attempt to preserve GIAHS sites by freezing them in time would surely lead to their degradation and impoverishment of the local community (http://www.fao.org/giahs/background/strategy-and-appro ach/en/). The best way to conserve agrarian cultural heritage is a system of active agriculture, meaning a productions system founded on economic results of food production. It is the most sustainable strategy to secure cultural heritage and other environmental values (Daugstad et al. 2006; An et al. 2020).

The purpose of the paper is to assess traditional agricultural systems in the Małopolska part of the Kraków-Częstochowa Upland using five GIAHS criteria: landscape features, agricultural biodiversity, food and livelihood security, traditional local knowledge systems, cultural values - in particular, systems of values - and social organisations that promote them.

The Kraków-Częstochowa Upland was selected as research area due to its unique historical, natural, social, and economic features. It has been part of Poland for ages and offers numerous historic sites among its unique in Poland topography (including outcrops and caves). It is also a sanctuary for endemic fauna and flora. The characteristic natural environment of the region drove specific farming regimes adapted to poor soils, complex river network, and numerous rocks. The 19th and early 20th centuries saw the first small industrial facilities, such as watermills.

For the purpose of the research, traditional agricultural systems mean those systems that have existed over the last two centuries and left only fragmentary traces today. The assessment yielded a proposal of a strategy for the spatial development of the area. The proposal is founded on the following thesis based on literature: cultural diversity and biodiversity are closely related. A loss of one of them is a risk to the other. Diversity of communities, cultures, and languages that has grown over the human history is strongly related to biodiversity and its use (UNEP 2010: 5). Consequently, the environment is a kind of an archive with records of cultural activities of humans over the history (Pretty et al. 2009). 


\section{The research area in light of the GIAHS potential}

A 160-kilometre long rocky range with a former capital of Poland, Kraków, on one side and Częstochowa, on the other is commonly referred to as the Kraków-Częstochowa Upland. Its natural environment, diversified types of settlements, long land use history, and combination of environmental and cultural elements are unique in Poland and internationally (Myga-Piątek 2008). The site has been historically Polish. It is there that the oldest traces of primitive humans in the territory of Poland were found. Its abundance of original rock formations has become entangled with the agricultural landscape over time. Settlements, villages, and towns grew. Thanks to its favourable topography, the Kraków-Częstochowa Upland was a popular place for strongholds. The castles that make up the Trail of the Eagles' Nests are fortified structures intended to defend trade routes in the young state built by the Piast dynasty. This historic landscape site is a background for hundreds of villages and dozens of towns (Uruszczak 2019).

With its rich karst landscape, diversified plant and animal life with endemic and relic species unique in Poland, the upland is a rather special region. The geomorphology is fragmented with clearly marked differences stemming from the geological structure, topography, and landscape.

The environmental qualities of the upland are protected with Ojców National Park, the Complex of Jurassic Landscape Parks, 18 preserves, over 360 nature monuments, four ecological sites, and eight documentation sites. The total area of the parks is 70,780 ha. Their buffer zones add 70,958 more hectares of protected land.

\section{Historical and economic background}

The natural environment of the Kraków-Częstochowa Upland has been shaped by human factors to a significant degree. The first traces of humans in the area date back to 120 thousand years BC, but the nomadic and hunter-gatherer communities of that day had little impact on their surroundings. The influence of primaeval cultures on the landscape and nature in the upland was negligible. It was not until the Neolithic about 4000 years BC that the impact of people started to grow, for example, in the form of burning down of forests to make room for the cultivation of plants and husbandry. In Europe deforestation intensified in the 6th and 7th centuries with the advent of the first fortified settlements. Soon, farmer colonies were established nearby.

The period from the 13th to 15th centuries was a time of significant landscape transformation. Most of today's villages, towns, and cities were laid out at the time. The area of primaeval forests shrunk dramatically due to clearing. To put hydropower to use and power industrial plants of all kinds, people built millraces in river valleys. Fish ponds and drinking water reservoirs were constructed. The 12th century marked the beginning of mining, first of lead, iron, and silver ore, and then coal as well. Numerous quarries were established as well. The exploitation lasted until the 17th century, when the resources grew scarce. The growth of settlements, metallurgy, and mining destroyed huge areas of forests by the end of the 18th century. Forests survived only in areas that were difficult to reach or far from settlements. Paradoxically, forest close to castles that had been parts of royal demesne since the 14th century made it in the best condition. The early 19th century saw a rapid industrial development in the western part of the upland with hard coal mines and zinc works. The construction of the railway line from Kraków To Mysłowice in the late 1840s facilitated 
further growth of the industry in the area. Mines and quarries followed the great expansion of the railway system. More significant localities attracted big industrial plants such as sawmills or brickyards. Another wave of development in the heavy industry came after the Second World War. The three largest state-controlled metalworking complexes were established at that time, Katowice Steelworks in Dąbrowa Górnicza, Vladimir Lenin Steelworks in Kraków, and Bolesław Bierut Steelworks in Częstochowa, with minor works in Zawiercie and Dąbrowa Górnicza. Most Polish zinc and lead ore is mined near Olkusz and then processed locally in the works in Bolesławiec. Hard coal (Siersza mine) and non-ferrous metal mining grew as well. The economic growth in the upland came at the expense of the natural environment. Slag heaps fouled the surface while waste and dust from factories polluted water and air. Most of Olkusz District and Chrzanów District are considered heavily transformed and degraded or at risk of degradation, causing a significant threat to human life and health and natural balance. They require quick and effective actions to improve the condition of the environment.

\section{Research materials and methods}

The assessment of traditional agricultural systems in the Lesser Poland part of the Kraków Częstochowa Upland using the five GIAHS criteria employed geospatial analyses, geoprocessing tools, a description-comparative method, and a landscape method. Input data were obtained from the Database of Topographic Objects (DTO10k). The DTO10k is a vector database with spatial locations and descriptions of topographic objects. The content and level of detail of the DTO10k are the same as for a 1:10,000 topographic map with such information as water network, transport network, utility services networks, land cover, buildings, structures, land use complexes, protected areas, or administrative divisions. The Head Office of Land Surveying and Cartography in Poland provided DTO10k data from the central Polish land surveying and cartographic inventory.

Data on natural environment protection were acquired from the website of the General Directorate for Environmental Protection, which keeps the Central Register of Nature Conservation Measures at crfop.gdos.gov.pl. The services are compatible with most geographical information system software, such as ESRI ArcGIS or QGIS, which can analyse and process data into the most popular formats, including ESRI Shapefile.

The research area was assessed with a SWOT analysis, which is believed to be a comprehensive, reliable, and effective method for strategic analyses (Weihrich 1982; Bozac 2008). With this method, research can focus on identified key strategic factors. The first step in the analysis was to select the primary beneficial and adverse factors followed by weighing by an expert judge panel. The authors then built contingency tables to determine interactions between possible combinations of external and internal factors (Gottfried et al. 2018).

\section{Identification of the agricultural and landscape potential of the Kraków-Częstochowa Upland}

In a trade economy, the agricultural system contributes to food security by providing local communities with livelihoods. The system includes self-sufficient, small-scale farming providing for internal needs. Mutual interactions help the agricultural economy grow. 
Map analyses and historical geography studies showed that rural economic and social life in the Kraków-Częstochowa Upland took a different course than in highlands and valleys. Dry areas on hills without water had limited opportunities for growth. At the same time, valleys were privileged settlement axes where water and its power defined the wealth of local communities (Myga-Piątek 2008). The densification of the settlement network that occurred at that time is clearly visible on archival maps representing networks of towns and villages entwined by a radial system of transport routes. Rural overpopulation in the 19th century led to farming on fallows, wasteland, and artificial clearings. Such types of villages as linear, Zeilendorf, or dispersed clustered continued to grow (Myga-Piątek 2008). The 19th and 20th centuries brought a division of the upland into two zones of different characteristics. The central area was dominated by agriculture, forestry, and craft in river valleys, while industrial influence was more pronounced in the southern and northern parts. Local communities worked in agriculture and plants producing for their respective lords of the manor (breweries, inns, quarries, etc.). The agrarian reforms from the 1920s and the 1924-1933 economic crisis exacerbated the difficult situation of the countryside. As a result of the socio-economic transformation after the Second World War, which turned Poland into a communist country, former manor demesnes in the Kraków-Częstochowa Upland were distributed among the people, which caused fragmentation of agricultural and forest land. The next step was to nationalise forests and established State Forest Holdings in places of home farms, and State Fishery Holdings took over the oldest fish pond complexes in Poland. Craft businesses were closed down or taken over by the state. Large watermills and factories were electrified (Myga-Piątek and Partyka 2003). Lack of financial support contributed to the degradation of former manor buildings. Built-up land grew more fragmented. Blocks of flats were built for workers of State Forest Holdings, which devastated unique spatial qualities of the upland landscape, including high-quality panoramas with outliers (for example, Karniowice) (see Fig. 1).

Today, municipalities in the Kraków-Częstochowa Upland are dominated by agricultural and forest land use types (Figs. 2 and 3). Forest land covers $35 \%$ and cultivated arable land $38.5 \%$ of the investigated area (60.8 thousand and 66.5 thousand hectares, respectively). Grassland constitutes $24 \%$ of the area (41.9 thousand hectares). Typical land use for the upland is orchards (mainly apple trees), taking up $1.5 \%$ of the area (2.5 thousand hectares), and occasional vineyards.

The modern transformations in the upland seem to focus on the appearance of settlement structures unified during communism and partially lost their regional identities (Bogdanowski 1997). Water resources have undergone functional changes as well. Consumption of water and use of power from rivers were replaced by fish farming and tourism. Today, river valleys serve mostly transport purposes (axes for road networks) and are tourist attractions. Recreation and tourist facilities are located there. Water resources, including underground water, and their quality have changed. Surface water retention structure has changed as waterlogged areas were drained and small ponds were created in flooded sand pits.

\section{Agrobiodiversity in the upland}

The diversity of plants and animals, also those not directly involved in farming activities, affect agriculture, in such domains as cultivation of land, husbandry, forestry, and fish farming, either directly or vicariously. Today, the connection between crop production and 

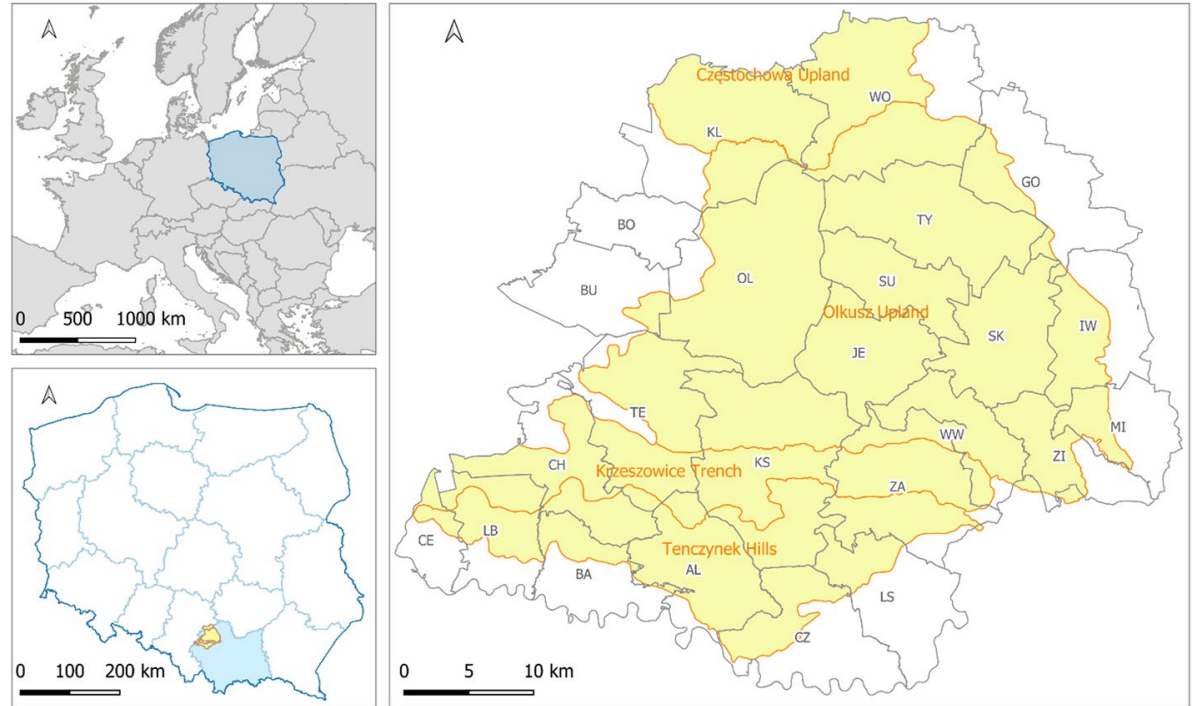

Fig. 1 The research area-The Kraków-Częstochowa Upland in Europe, Poland (Małopolska). The part of the upland situated in Małopolska covers four mesoregions, the Częstochowa Upland, Olkusz Upland, Krzeszowice Trench, and Tenczynek Hills. In terms of territorial subdivision of Małopolska, the upland covers 24 municipalities. They are: AL-Alwernia, BA-Babice, BO-Bolesław, BU-Bukowno, CE-Chełmek, CH-Chrzanów, CZ-Czernichów, GO-Gołcza, IW-Iwanowice, JE-JerzmanowicePrzeginia, KL-Klucze, KS-Krzeszowice, LB-Libiąż, LS-Liszki, MI-Michałowice, OL-Olkusz, SK—Skała, SU—Sułoszowa, TE—Trzebinia, TY—Trzyciąż, WO_Wolbrom, WW-Wielka Wieś, ZAZabierzów, and ZI-Zielonki. Source: Database of Topographic Objects (DTO10k)
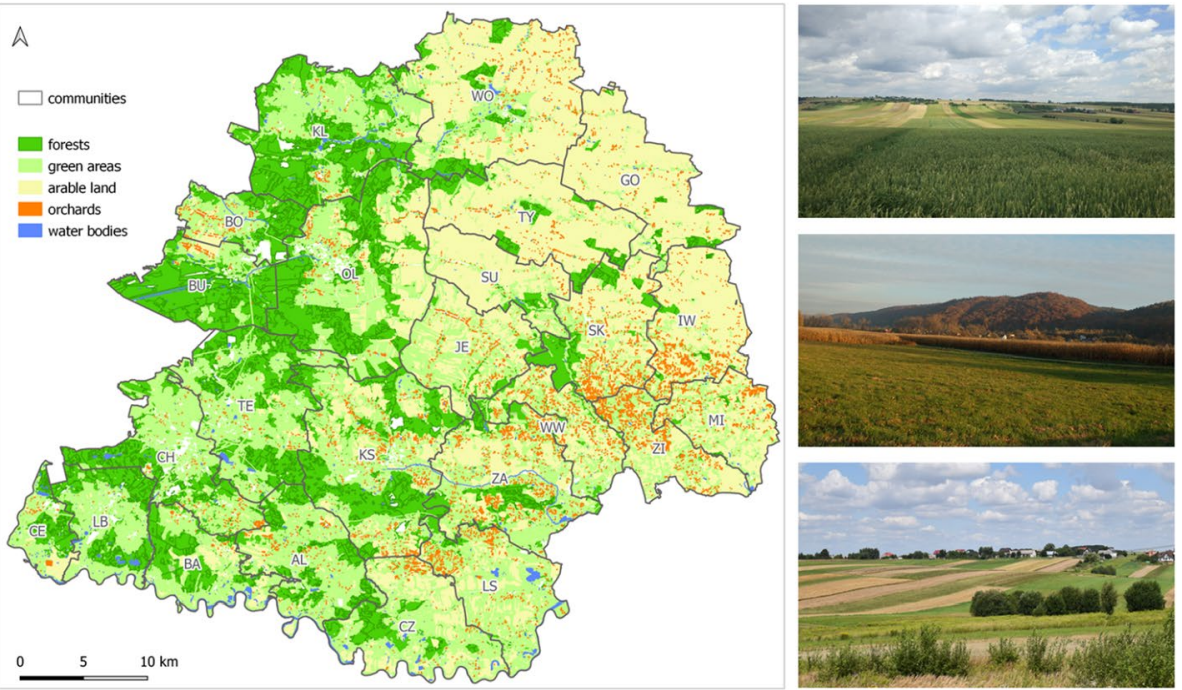

Fig. 2 The agricultural and forest potential of the Kraków-Częstochowa Upland. Source: Database of Topographic Objects (DTO10k). Photos by S. Bacior and M. Uruszczak 


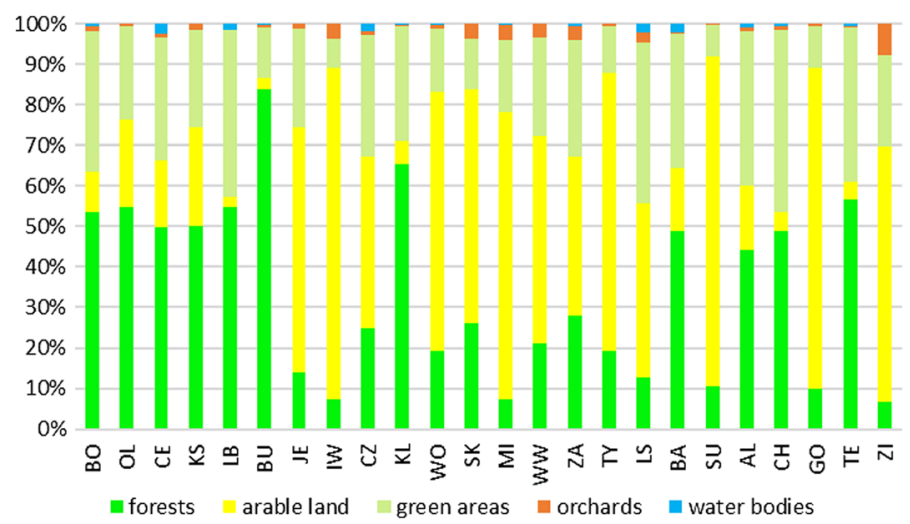

Fig. 3 The share of land cover types in the total areas of the municipalities in the upland

husbandry grows weaker. Animals lost their functions (as work animals, recyclers of harvest waste, or producers of manure) and are no more found in agriculture of autonomous production units, which further degrades landscape diversity (Agnoletti 2014). The upland biocoenoses are arranged in a clear mosaic. Groups of plants with highly different environmental requirements grow side by side in a relatively small area. The interfaces between such communities sometimes reach mere dozens of centimetres. With extremely diversified topography, Kraków Valleys and Ojcowski National Park offer over a dozen plant communities on several hectares, which results in significant biodiversity and abundance of species comparable to large mountain ranges.

The upland has about 60 natural and semi-natural plant communities. Over 16 different forest associations were identified in forests of the upland, which take up about $20 \%$ of the area. The most interesting are relic mountain associations far from their usual boundaries. The shaded slopes of valleys preserved Dentario glandulosae-Fagetum Klika $1927 \mathrm{em}$. Mat. 1964 and Phyllitido-Aceretum Moor 1952. Another valuable community is MedioEuropean limestone beech forests of the Cephalanthero-Fagion, representing a south European component on sunny slopes, rocky slopes, and limestone hills. One of the rarest forest communities in Poland is the riparian elm forest. It can be found in merely several sites in Poland, including in the Prądnik valley in Ojcowski National Park (Michalik 1993).

However, the upland landscape is dominated by communities other than forests. Xerothermic grasslands, with their abundance of species and most flowery biocoenoses in the upland that are reservoirs of rare and often relic animal and plant species, are particularly unique. Valley bottoms offer numerous semi-natural meadow communities along streams with different humidity levels and increasingly rarer peatland and reed bed communities. Rapid karst streams and sources form a separate environment typical of the upland. They are rich in oxygen and carbon dioxide, which helps with lush vegetation, covering stream bottoms for almost the entire year. The southern boundary of the upland is the Vistula valley. This area has numerous oxbow lakes that, together with nearby shrubs and wet meadows, are valuable ecosystems.

The upland has developed or retained from previous climate periods very rich vegetation not found anywhere else in such diversity due to the significant variability in habitat conditions. Furthermore, the area offers over 800 species of mushrooms, more than 400 species of mosses, and the same number of lichens. The place houses numerous protected species, also those on the red list of endangered species of plants in Poland. Most species 
of Orchidaceae are protected and included on the red list. The upland is home to a group of boreal species. For example, Carex globularis can be seen in Vaccinio uliginosi-Pinetum sylvestris in Dulowska Forest, $500 \mathrm{~km}$ south of its regular distribution area. An endemics, found only at a transplantation site in the Kraków-Częstochowa Upland, is Cochlearia polonica. It is a protected species, included on the IUCN Red List in 1983 (category EX/E), listed in the Polish Red Data Book of Plants (category EW), Polish Red List of Vascular Plants (category EW) (Inanimate nature monument 'The Centuria River Sources Association').

The fauna of the upland is abundant and diverse as well. Over 50 species of mammals, 170 species of birds (including 150 breeding), about 20 species of amphibians and reptiles, and 25-30 species of fish have been identified there. Invertebrate are represented by over 1200 species of butterflies, 700 species of beetles, 250 species of Apidae, and nearly 100 species of molluscs. Due to a high human population density, large mammals are scarce. The most prominent of them is the moose in Dulowska Forest. Other mammals include the roe deer, wild boar, badger, European pine marten, European hare, beaver, otter, and the European hamster. Bats are of particular environmental value. From among 21 species of bats found in Poland, 19 can be seen in the upland. No other region in the country has such a number. Invertebrate are numerous. A large share of them are xerothermic animals typical of warm regions of southern and south-eastern Europe and Asia (Michalik 1993; Staszkiewicz 1986). The agricultural land in the upland is dominated by wheat soil complexes in the east that form the agricultural potential of the area. They are complemented by sandy rye soil complexes in the north (Fig. 4).

The upland has been under considerable threat in recent decades due to the decline of pasturing, intensification of agriculture, and resultant multidimensional land use changes, afforestation, clearing, and conversion into arable land. Other substantial threats are the spread of alien species and secondary succession. Poor quality soil land that is difficult to
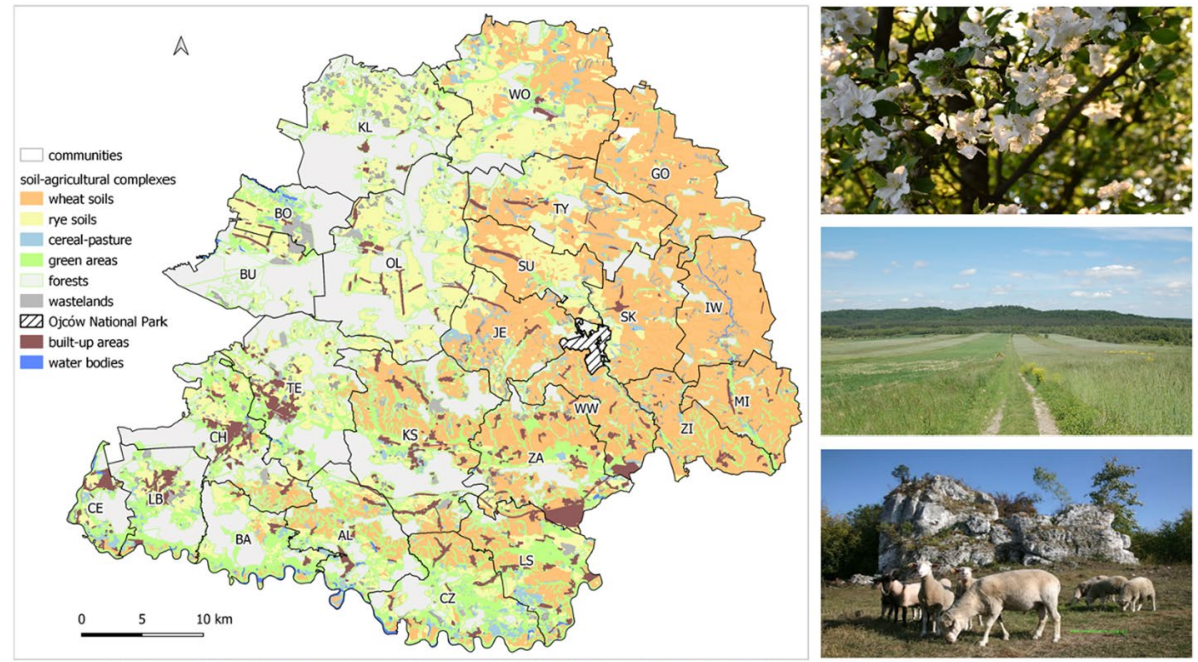

Fig. 4 The distribution of agricultural soil complexes in the research area. Agricultural soil complexes are soil taxonomy units for the territory of Poland that group soils with similar agricultural properties that can support similar use. Soil cultivation suitability is defined by the cultivation of indicator plants: wheat, rye, oat for mountainous regions, and potatoes. Source: Map: Database of Topographic Objects (DTO10k). Photos by M. Uruszczak and from http://www.podlesice.org.pl/aktualnosci/142/ 


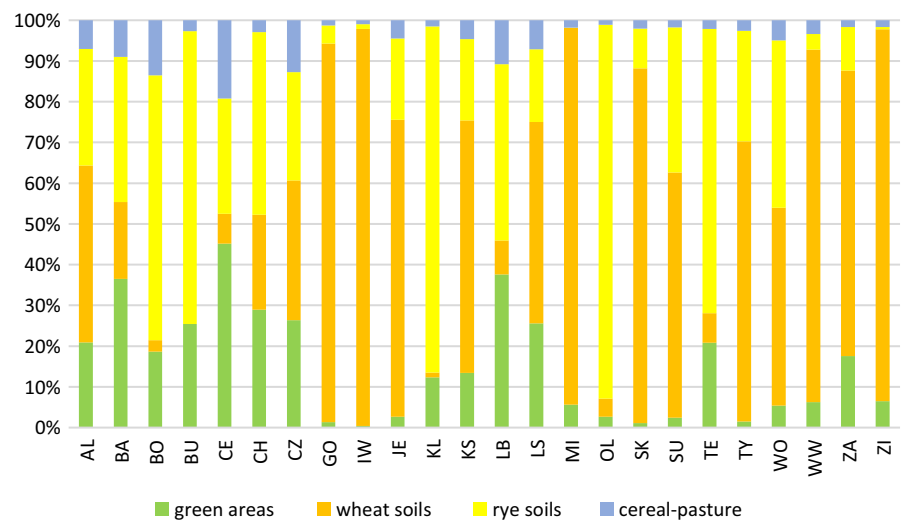

Fig. 5 The structure of agricultural soil complexes in the area
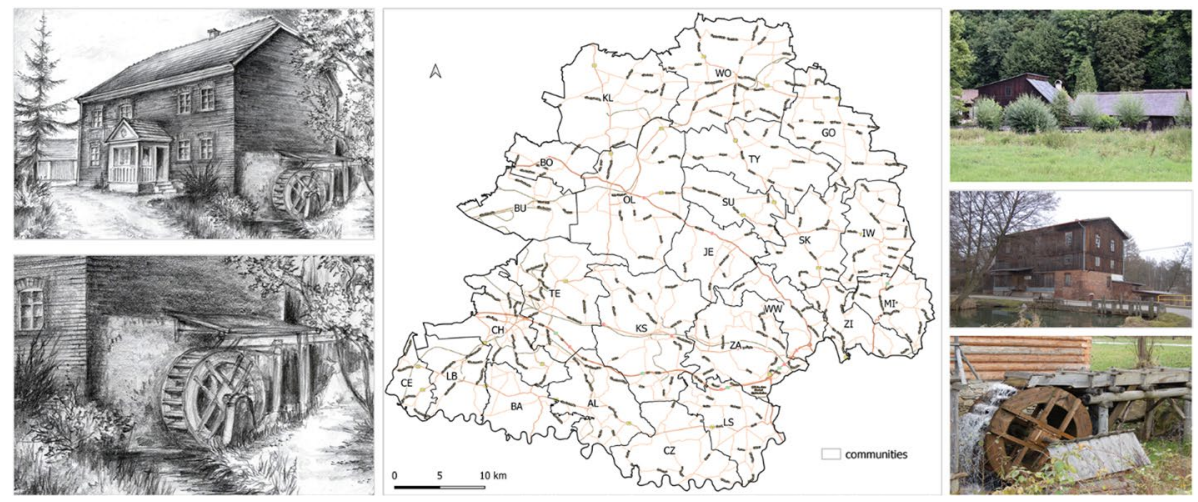

Fig. 6 Grain and malt watermills in valleys of numerous rivers in the Kraków-Częstochowa Upland. A map of the upland road network. Source: Database of Topographic Objects (DTO10k), photos and sketches by M. Uruszczak

cultivate is gradually abandoned due to the low economic viability of farming. Arable land undergoes ecological succession and is taken over by forests, which increases forest cover. Sixty per cent of the upland is podsolic soils. Only the Olkusz Highland has brown soils, and the eastern boundary of the upland has rendzinas (Bronisz et al. 1994) (see Figs. 5, 6, 7).

The decline in agricultural land and increase in forest cover harmed biodiversity in forest-meadow and forest-agricultural zones. Natural field boundary stripes and Rubo fruticosi-Prunetum spinosae, which harboured numerous bird, small amphibian, and mammal species, are taken over by pine monocultures (Bronisz et al. 1994).

Similarly to other areas, forest landscapes in the upland were seen to change their profiles. They are now large coniferous monocultures that replaced deciduous trees as a result of an approach promoted by early 19th century forestry sciences (Johann et al. 2004). Today, the research area is generally undergoing changes. This leads to a reduction of what used to be a broad array of traditional forestry systems, such as forest that can accommodate livestock grazing and production of fruit for human consumption, vanishing of 

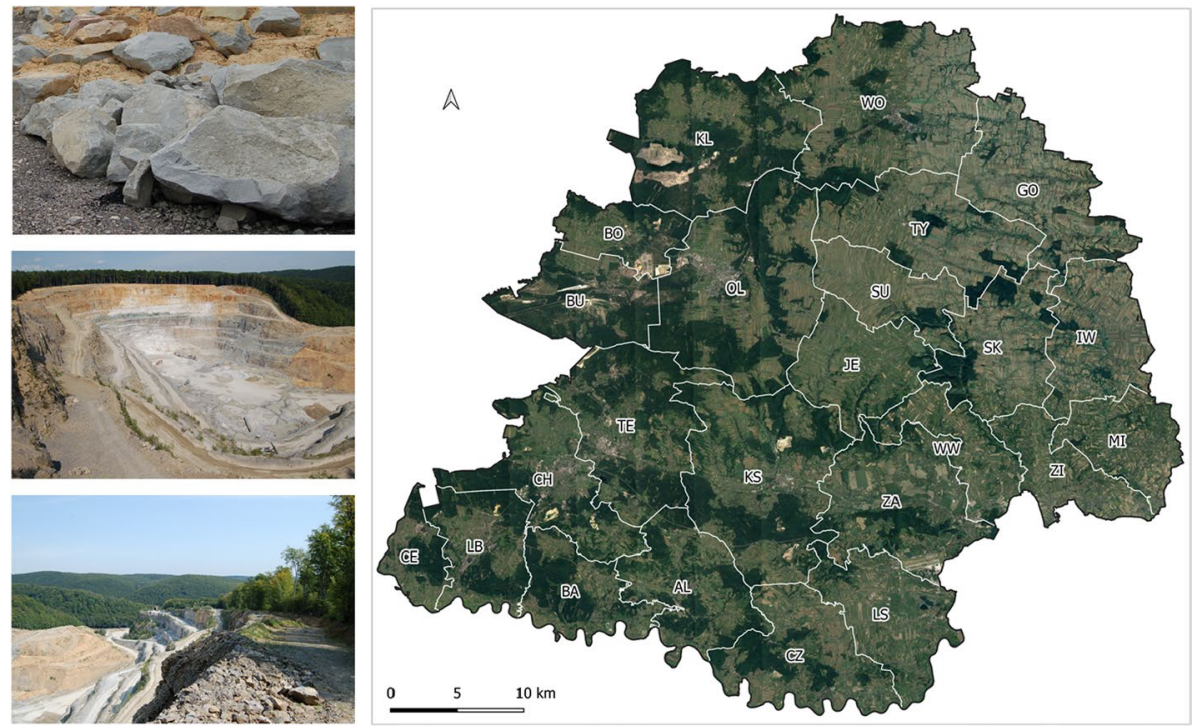

Fig.7 Quarries in the Kraków-Częstochowa Upland. Source: https://www.geoportal.gov.pl/, Photos by M. Uruszczak

afforested meadows, bushy areas, forests for feed production, groves, resin extraction, and many other forestry systems related to agriculture (Agnoletti 2014). The discontinuation of grazing was often supported by environmental protection strategies, particularly in areas under legal protection.

Despite controversial farming conditions, the upland is famous for its garlic, soft fruit (strawberry and raspberry), trout farms and vineyards. The beginnings of garlic farming in the area are lost in the mists of time. The vegetable is served as a medicine, seasoning, tincture, or the main dish. There is even a special day to celebrate it. Now that the climate is more favourable, vineyards are returning to the upland after they were abandoned in the late Renaissance. Vineyards in Bielany, Kraków, Burów, and Olsztyn are being restored. There also used to be vineyards in Tomaszowice, Aleksandrowice, Balice, and Korzkiew. Examples of good practices show that agrobiodiversity can be a condition of financial support under aid schemes (Ravetto 2020).

\section{Local traditional knowledge systems}

Folwarks, large agricultural family holdings for large-scale production for sale, were common in the Kraków-Częstochowa Upland. More than a hundred folwarks are believed to have operated in the area in the 19th century. Rural transformations are now reflected in names of fields: 'pańskie' [lord's], 'folwark', and 'na pańskim' [on lord's land] but also in a dense network of manor buildings (Myga-Piątek 2008).

The 19th century was the golden era of water craft in the upland. Valleys of the Pradnik, Krztynia, upper Warta, and Ordonówka were small industrial regions in and of themselves (Falniowska-Gradowska 1995). The most common facilities on rivers were grain and malt watermills, groats, oil, and powder mills, paper and fulling mills, tanneries, sawmills, 
hammer mills, iron prefining plants, tool making plants, sabre makers, and others (MygaPiątek 2004a). These small industrial facilities could process produce to meet local needs.

Today, the flagship characteristic feature of the Prąnik Valley is numerous watermills on the stream. The oldest and most precious one seems to be the Boronia watermill and sawmill in Grodzisko (the mid-19th century). Presumably, there was a mill there as early as in the 15th century. Six other mills were built in the 19th century. Three mills in Wola Kalinowska were built in the early 20th century. Another noteworthy object is the historic watermill in Kacice, Słomniki municipality.

Settlements in the upland after the Second World War exhibited two main features typical of the rural development at that time. The first one was 'idolisation of the city' both in terms of lifestyle and interior and exterior design of buildings and infrastructure on a parcel, in a village, or a neighbourhood. The other one was unification, or standardisation of architectural forms completely at variance with regional vernacular architecture. In some cases, certain similarities could be identified in how the Jurassic building material, limestone, was used.

Urban patterns were proposed in rural areas of the upland as models to follow, which often resulted in no provisions for dump sites, water treatment plants, or fixed recreation and tourist facilities. Urban settlement patterns were introduced to the rural areas without any proper infrastructure. The $1970 \mathrm{~s}$ saw the law of 'designated development areas' as specified in then-spatial development plans. It fuelled a dangerous trend of dispersed development in the local cultural landscape. It continued until the late 1980s. The period from 1990 to 2000 introduced new 'trendy' architectural models, while the urban-to-rural migration grew. After 2000, 'urban' spatial arrangements grew stronger in the countryside due to the activities of building developers. It involved 'urban' patterns of regular parcel subdivisions, gated communities with identical single-family houses, etc.

The traditional rural building in the upland had a single row of rooms and thatch or, less frequently, tile roof. It had stone stables or cowshed in the west. The front wall faced south. The entrance hall was in the centre. Exterior walls came in 'diverse variants': Beams were left untreated. Particularly more carefully finished houses had white or blue limewashed walls. The cottages were painted in colourful stripes. Near Kraków, people often painted the spaces between beams. Beige elevations can be seen in Liszki and Alwernia. Some barns in the upland were built using a special 'wicker basket' structural design, an approach unique in Poland. During construction, a wicker mesh was fixed to a wooden frame. Another unique solution is the roof sitting on pillars outside the walls instead of being supported by the walls. Such houses can be found in the Kraków area. Some rural cottages were supported on rocky outcrops. Thanks to the rocky subgrade, they had no foundations; just small wall bases. They can be found in Jerzmanowice, Sułoszowa, Ojców, and their vicinity. Ojców has a 'chapel on water'. This peculiar design stems from a ban by Russian invader authorities to build a church 'on the ground'. The church (chapel) was constructed on a bridge over the Prudnik. Ojców is special due to its spa function and architecture, gigantic wooden hotels. In his book 'Polish Gardens', Gerard Ciołek wrote about terraced rock gardens, which he believed to be works of folk art. They emerged from difficult topographical conditions. The gardens are, in fact, dry stone 'walls' along field boundaries (for example, in the village of Niegowonice).

Today, traditional houses built according to local, rural architectural principles and with regional style are vanishing. Traditional buildings are demolished and redesigned. Traditional flower gardens change. The phenomenon is referred to as conscious urbanisation of the rural landscape (Myczkowski 1997). Local traditions include dożynki, a harvest festival. It is a feast with dancing at the end of the harvest season. It used to be preceded by rituals 
and prayers. In the late 19th century, peasants started to organise their festivals modelled after feasts taking place at manor houses. Affluent farmers held them for their extended family and hired hands. Dożynki was a display of peasants' individuality and pride in being a farmer. They included such fringe events as agricultural exhibitions, fairs, and performances by folk artists (Ogrodowska 2004). The end of harvest was celebrated in churches as well. Each parish church blessed bread and harvest wreaths, which were very diversified in Lesser Poland (Reinfuss 1960).

\section{Cultural identity, systems of values, and grassroots organisations in the region}

The regional identity of the Kraków-Częstochowa Upland is a special case of social, cultural, and historical identity based on regional traditions related to the distinctively defined and delimited area of the upland and its specific sociocultural features, including symbolic, economic, and topographic features that make it stand out among other regions. The unique character of the upland is also embodied in grassroots organisations that promote local traditions, traditional values, and customs. These organisations include prevalent farmers' associations, farmers' wives' associations, and local activity groups drawing on regional history and traditions.

Farmers' associations unite generations to advocate interests of the Polish countryside and individual farmers. The traditions of such associations date back to 1862. In Poland's history, farmers' associations defended national values. Their activists took part in many insurrections and independence wars. They went down in history as the only and persistent agricultural organisations. Today, over 25 thousand farmers' and farmers' wives' associations are social and professional organisations of farmers and their families. Farmers' associations form nearly a thousand cooperatives that provide services to family holdings. Farmers' associations are members of European and global agricultural organisations and held European and global agricultural conferences. The next year, it will be the 150th anniversary of the establishment of farmer's associations.

A farmers' wives' association is a distinguished and autonomous unit within a farmers' association. It is a voluntary and self-government social and professional organisation of farmers independent of state administration and social organisations. Farmers' wives' associations are intended to participate in the formation and implementation of agrarian and social policies to further economic, public, social, cultural, and educational progress in rural areas. Over the decades, associations focused on helping rural families bring up, educate, and provide leisure for children and youth, aid healthcare and welfare, develop women's entrepreneurship, streamline rural household operations, increase the cultural activity of people in rural areas, and actively preserve folklore. Even now farmers' wives' associations activate young women by promoting regional folklore, traditional cuisine, or local craft. In addition, they add colour to shows and exhibitions. Another type of grassroots organisations found in the upland is local activity groups. They are a kind of territorial grassroots partnership of local public, private, and NGO sectors joined by residents to take action for the local community. There are seven local activity groups in the investigated area. Their names and activity profile draw on historical qualities of the KrakówCzęstochowa Upland (Fig. 8), such as 'Jurajska Kraina' [Jurassic Land] or 'Partnerstwo na Jurze' [Partnership on the Upland]. 

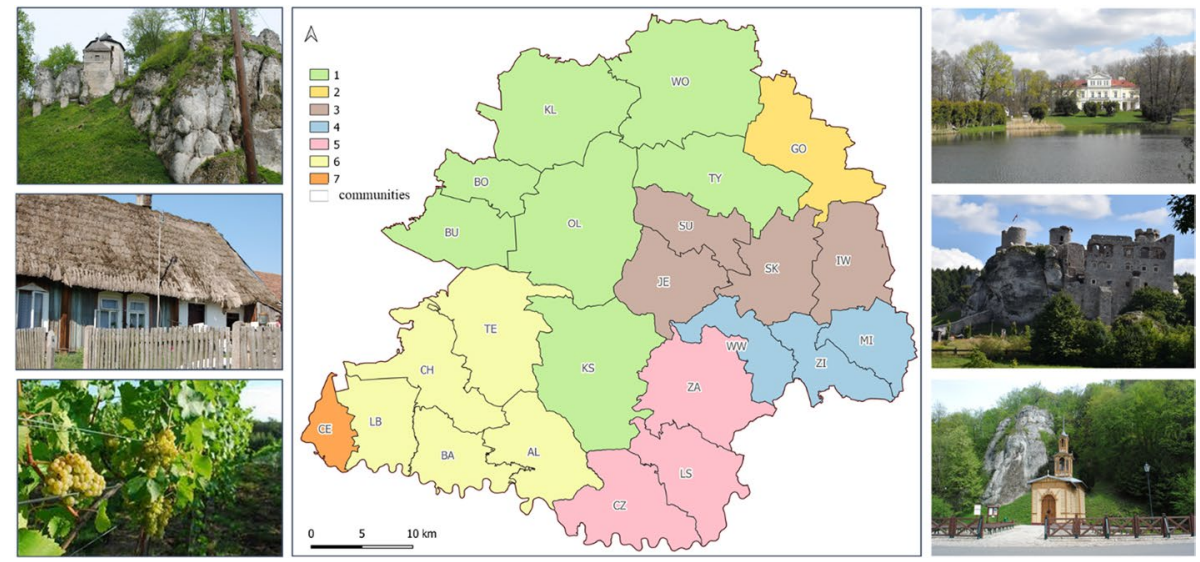

Fig. 8 Local activity groups in the area: (1) Local Activity Group Association 'Under White Przemsza', (2) Jaksa Local Activity Group Association of Municipalities in Miechów, (3) Local Activity Group Association 'Jurassic Land', (4) The Crown of Northern Kraków Association, (5) 'Close to Kraków', (6) Local Activity Group 'Partnership on the Upland', (7) Local Activity Group Association 'Soła Valley'. Source: http://malopolskie.ksow.pl/malopolskie-lgd, photos by M. Uruszczak

\section{Cultural agrarian landscape}

The dynamics of changes in the landscape and farming system in the Kraków-Częstochowa Upland suggest another developmental stage has begun driven by historical processes. It is, therefore, necessary to determine actual threats to the natural and cultural landscape brought by intensive human activity in the area. The beginning of the protection and conservation of the upland was the legal protection in the form of six landscape parks and a national park (Figs. 9 and 10).

Small agricultural holdings providing food for the local community are part of the protected rural landscape there. The mosaic of agricultural fields and ponds with a significant share of cultural elements and spatial structures and components has been moulded by joint impacts of natural and designed land cover and spatial structure modification. Still, this landscape offers natural and cultural qualities (Verschuer 2021). The landscape background is, often chaotic, bands or mosaics ('patchwork') of small arable fields, meadows and pastures, orchards, wasteland, and groups of trees, none of which dominate. Fields differ in size, but the most common are parallel parcels of different shapes and areas, most often up to 2 ha. The presence of dispersed developments in the upland varies (Chmielewski et al. 2015).

The most strict measure for environmental protection in Poland is the national park. It covers an area of not less than 1000 ha with special environmental, scientific, social, cultural, and educational values where all nature and landscape qualities are protected. National parks are established to preserve biodiversity, inanimate environment resources, objects, and components, and landscape qualities. They are further intended to restore the proper condition of resources and components of the environment and changed natural habitats, plant, animal, or fungi habitats.

A less restrictive type of environmental protection regarding agriculture is the landscape park. It is established in areas protected due to their natural environment, historical, and cultural values and landscape qualities to preserve and promote these values sustainably. 


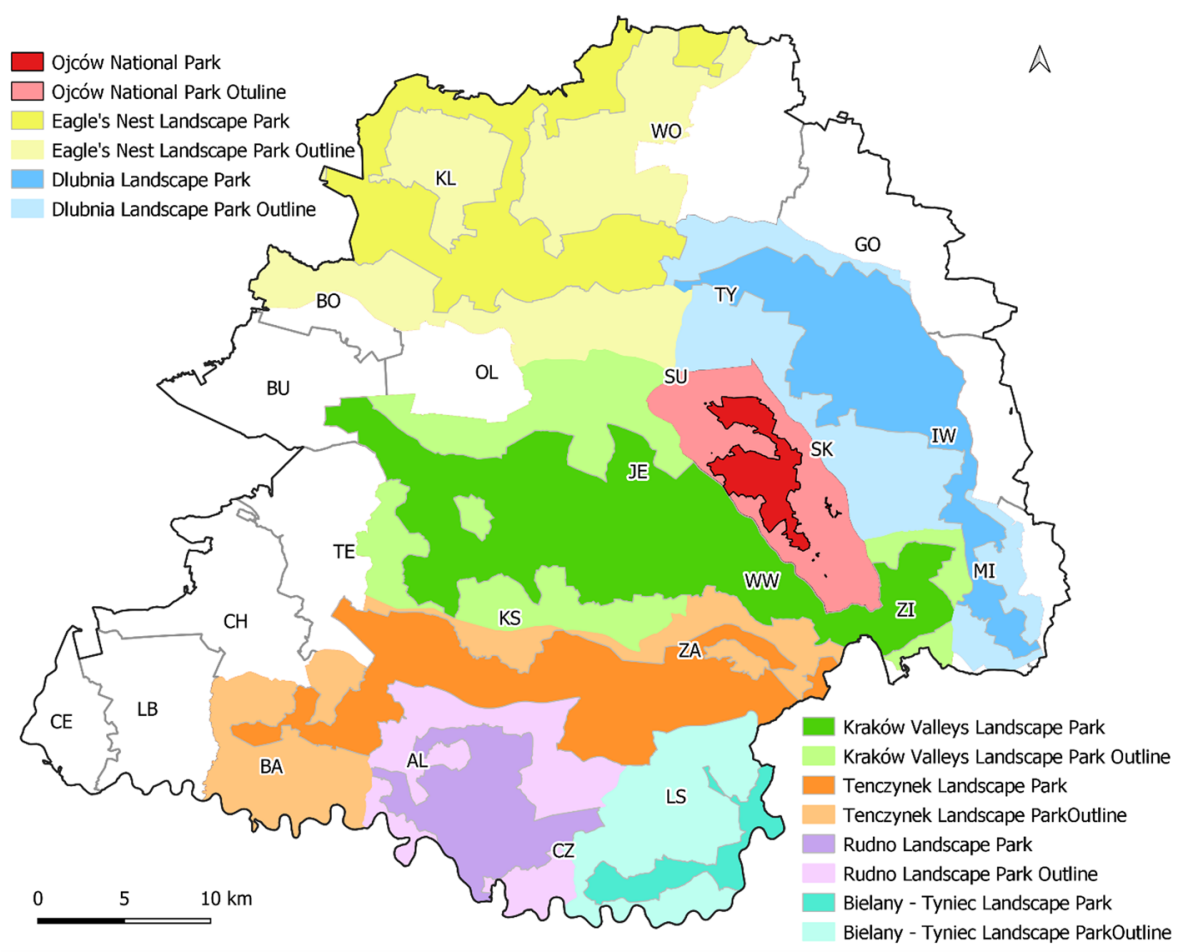

Fig. 9 The national park and landscape parks with their buffer zones in the research area. Source: Central Register of Nature Conservation Measures at crfop.gdos.gov.pl

The upland, for example the Eagles' Nests Landscape Park, offers beautiful landscapes, animate and inanimate nature, and several cultural heritage sites, mainly churches and Medieval castles. They were built on inaccessible limestone hills comparable to eagles' nests (Sroczyńska 2018). With proper conservation and adaptation, the upland can offer a great and rare work of past spatial planning to the public, the fortified line. The current conservation effort strives to preserve its full authenticity, which can provide an exceptional research and teaching opportunity that will draw tourists when combined with old routes and landscape qualities (Bogdanowski 2002; Santoro et al. 2020). The upland is home to the only in Poland Błędów Desert, numerous limestone formations, and very precious forest ecosystems, mainly Fagion sylvaticae.

The area of all parks and reserves in 24 Lesser Poland municipalities in the KrakówCzęstochowa Upland covers $36.7 \%$ of the investigated area. Ojców National Park takes up $1.1 \%$ of the area, and the six landscape parks (buffer zones excluded) occupy $36.7 \%$. The environmental protection measures implemented in the area significantly impact the agricultural landscape through restrictions and prohibitions regarding shaping the landscape and developing the agricultural function there. The environmental protection measures sidetracked the traditional agricultural system in place since the 1980s. 


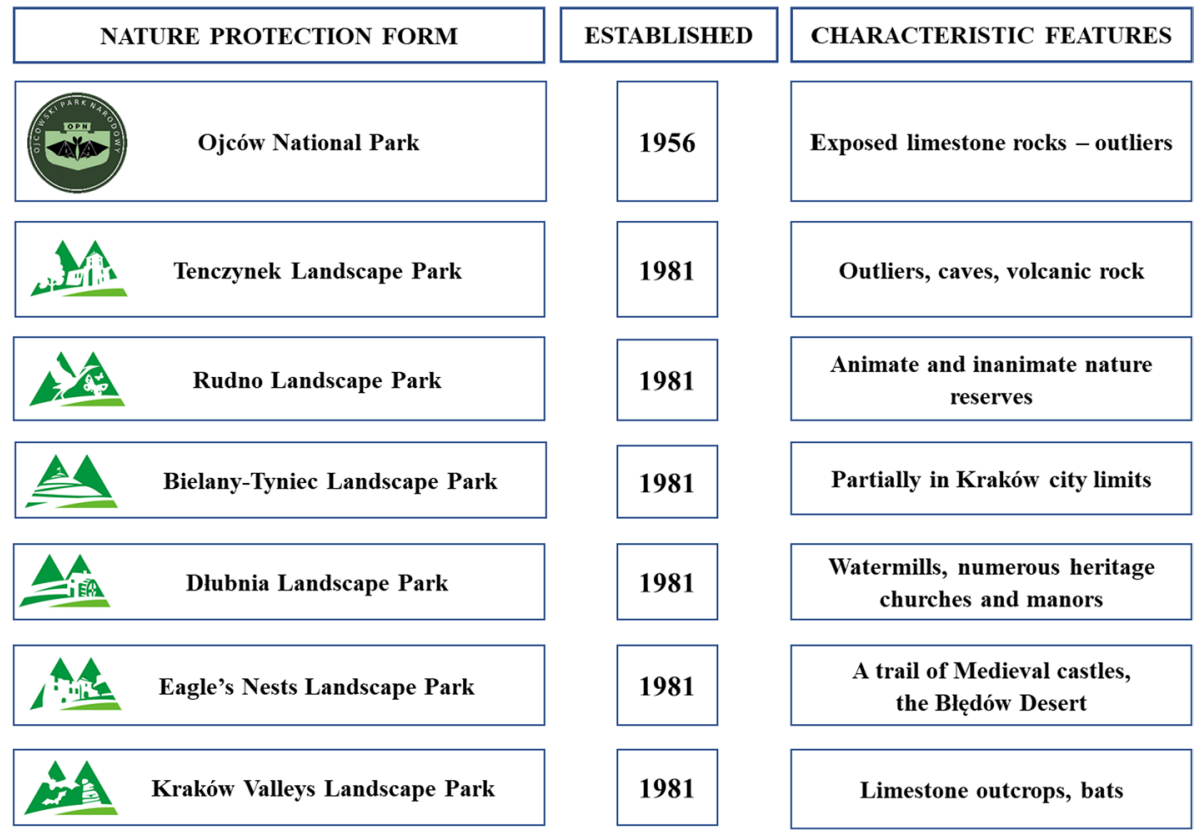

Fig. 10 Summary of legal means of environmental protection in the area

\section{Action plan for the persistence, continuity, and vitality of the agricultural system}

\section{Monitoring (identification and analysis) of threats and challenges, including socio-economic pressure and environmental changes}

The landscape of the Kraków-Częstochowa Upland has to be protected due to a large number of accumulating threats of the standardised popular culture. Inanimate components, such as historic buildings, outliers, or unique combinations of views, require conservation as well.

The upland has two primary aquifers: the upper Jurassic Częstochowa aquifer and Triassic Olkusz-Zawiercie aquifer. Deep undergroundwater intakes in the upland usually have no indirect protection zones or associated land use restrictions whether the water is used for industrial or public purposes. These circumstances mean there is a risk of water and ground pollution near the intakes. The western part of the upland is affected by largearea changes in water resources conditions. Both all aquifer levels and surface waters are influenced. The transformations stem from heavy drainage in mines and deep intakes of industrial plants. Operational quarries also disturb the natural environment of the upland. Most of them are situated close to valuable environmental sites, protected forest areas like the Eliaszówka Valley reserve near Czatkowice with one of the largest limestone quarries in Poland (120 ha). Another example is the Racławka Valley reserve between a dolomite quarry in Dubie and a limestone quarry in Dębnik. There is a Niedźwiedzia Góra diabase quarry right in the centre of the forest complex of Tenczynek Landscape Park. Apart from significant changes in the landscape, exploitation of rock raw materials is a significant 
threat because of heavy machinery, use of explosives, and road transport. Road traffic is one of the greatest threat to the natural environment in the upland. A well-developed network of roads improves accessibility to most nooks and crannies there. Moreover, it poses a strong barrier, which hinders or even prevents connectivity among ecosystems.

Reclamation of meadows near Tynieckie Hills, the Rudawa valley, Dłubnia valley, and Dulowa destroyed habitats of many valuable species. Apart from reclamation of meadows and forests through drainage and open drains, also filling-in of small reservoirs contributed to the lowered water table. Today, hygrophytes are at the greatest risk of extinction due to disturbed water resources conditions. The upland's landscape, environmental, and cultural qualities and proximity to large agglomerations stimulate a strong tourist presence. Many locations are above their tourist capacity. The problem is particularly apparent in Ojców National Park and Kraków Valleys. Ojców National Park is the smallest national park in Poland, but the tourist volume per hectare is the highest. It is visited by about 400 thousand tourists a year, mainly on spring to autumn weekends.

The upland is slowly losing its typical agricultural nature, turning into a dormitory for nearby towns and cities. Abandonment of agriculture, short distance to a city, good road network, and infrastructure result in intensive development and urban-to-rural migration. Hence, the value and attractiveness of a landscape can pose a threat to its quality today (Spielhofer et al. 2021; Wartmann et al. 2021). The most in-demand parcels for residential buildings are those with the most alluring landscape far from developments. Parcel value is pushed up by the vicinity to cultural heritage sites, nature monuments, or reserves. Building up of such places irrevocably damages landscape qualities and causes fragmentation of the environment, disruption of wildlife corridors, and isolation of natural habitats. Houses are built among fields and meadows, which entails constructing new roads and utility services, promoting further development. Not only do fences cut across streams and include them in private areas at variance with the water law, but they first and foremost hinder or block the migration of animals.

\section{Implemented strategies and local policies}

The Kraków-Częstochowa Upland landscape emerged from centuries of interactions between residents and the environment. The changes the area undergoes disturb the spatial harmony embodied in the patchwork of fields, boundary strips, brushwoods, forests proper for each habitat, and permanent building lines (Przegon et al. 2017). One of the most important problems with the landscape approach to environmental protection is biodiversity. It is, in turn, related to the structure of cultural landscape and needs to be identified (Agnoletti 2014) before support schemes are drafted. Agrarian landscapes can play a direct role in the preservation of 'agricultural biodiversity' (Wagner et al. 2000).

Open spaces are replaced by small parcels limited by concrete fencing to emphasise private property. On the other hand, examples of care for the landscape, such as careful conversions of old houses, homesteads, barns, and manors cannot go unnoticed. Entire peasant settlements are recovered, for example, in Złoty Potok. Minor structures and features, such as windlass or sweep wells, rural ponds (kaczeniec), and wayside chapels, shrines, and crosses, receive careful treatment. Numerous agritourism farms use such local products as trout dishes, honey, and herbal liqueurs. Educational centres at the offices of Ojców National Park and the six landscape parks offer substantial and still growing learning opportunities. 
Environmentally valuable non-forest habitats unique to the Eagles' Nests Landscape Park are actively protected in the upland. Residents of nine municipalities that are partners in the project are encouraged to take action through familiarisation with environmental protection and an indication of ways to ensure rational agriculture and tourism (project LIFE11 NAT/PL/432).

An effort to restore the former landscape of unique picturesque rocky formations has commenced in the upland in the $1990 \mathrm{~s}$. The main focus is to clear trees and shrubs that have grown there since pasturage stopped. The next step is to put out sheep or goats, often mixed. The natural role of the animals is to graze and thus reduce the growth of removed trees and bushes. Small sheep hoofs break up local concentrations of humus. The sheep move around and compact the soil, strengthening roots, improving plant species density, and preventing soil erosion. Seeds can travel significant distances in fleece or digestive tracts to find new, better sites. This procedure can restore the traditional cultural landscape from dozens of years back in several years. Native breeds are strongly related to their regions of origin and occurrence. One approach to their active conservation is to reinforce their position in the local culture and landscape (Sosin-Bzducha et al. 2012).

Training workshops delivered in 2015 attracted 3380 people. Field trips to xerothermic grasslands added to the allure of the training and perfectly consolidated new knowledge. Participants learnt about the characteristics, and conditions for xerothermic and rock grassland and vegetation found in these communities. The participants were positively thrilled by pasturage opportunities under the project. Goats and sheep are referred to as 'eco-mowers' and they lived up to this name when they perfectly demonstrated this highly effective method for active conservation of thermophillic biocenoses. The workshops helped people realise the importance of pasturing for environmental protection and the upland landscape and learn the value of habitats found in the Kraków-Częstochowa Upland.

The Environmental and Cultural Heritage Centre in Podlesice is the venue of 'Jurajskie Regionalia', an event held by the Society of Zawiercie Region Enthusiasts. The purpose of meeting with the local community is to promote and celebrate the traditions and cultural heritage of the Kraków-Częstochowa Upland and present active environment protection efforts. It is a promotion of natural and landscape qualities of the upland among local people, visitors, and tourists and a great opportunity to educate the guests about xerothermic and rock grasslands and how to protect them. Children and youth are educated through fun and creative experiences.

Project LIFE+ 'Protection of environmentally valuable non-forest habitats specific to Eagles' Nests Landscape Park' is a reaction to adverse changes in xerothermic grassland and an effort to protect the valuable endemic, Cochlearia polonica. Lower areas among outliers are most often covered in fluvioglacial sands where river valleys have formed (mostly in the southern part of Eagles' Nests Landscape Park). The dominant vegetation is Dicrano-Pinion. The main threat to Cochlearia polonica is the change in water resources conditions, growing number of summer houses, shadowing of its site by the canopy, or growth of horse mint (Mentha longifolia) in a part of the source niche. Buyout of land, including places where Cochlearia polonica grows, is one of the most effective site protection methods. The project was co-funded by the European Union under the LIFE + funding instrument to protect habitats in Eagles' Nests Landscape Park. It scored the best among all European environmental applications (Project LIFE11 NAT/PL/000432).

In 2007, the upland was included in the landscape protection network NATURA 2000 (Newsletter Natur der Generaldirektion für Umwelt der Europäischen Kommission 2004, Amtsblatt der EU-2007) with site code PLH-120,014. The Błędów Desert has been classified as a site of Community importance (SCI). The most serious threat faced by the desert 
is the ecological succession of forests around it (volunteering) and artificial afforestation [NATURA 2000. Standard Data Form 2008]. Projects for ecological restoration of afforested areas of the desert are being developed. It is a spectacular organisational challenge for local authorities in adjacent municipalities. Trees and shrubs should be consecutively cleared from an area of about 2000 ha over dozens of years (Bryś and Gołuch 2011). Project LIFE09 NAT/PL/000259 'Active conservation of a priority sand habitats complex $(6120,2330)$ in the Natura 2000 site Błędów Desert' of the Municipality of Klucze is aimed at providing adequate protection for the largest complex of xeric sand calcareous grasslands and inland dunes with open Corynephorus and Agrostis grasslands. The deployment of active conservation in the desert will help improve the condition of the habitats significantly through a direct ecological effect at the Natura 2000 site. It will also be an opportunity to test and disseminate good protection practices in other similar areas in Poland and Europe.

In late 2019, residents, local politicians, environmentalist organisations, and people who care about the upland wrote a petition to the government, Polish National Commission for UNESCO, UNESCO World Heritage Centre in Paris, many other institutions, and media. It was a request to advocate the idea to include the Kraków-Częstochowa Upland on the World Heritage List. The authors of the appeal believed it would protect the environmental and cultural assets of the upland from threats related to the anthropogenic degradation of the natural environment.

\section{SWOT/TOWS analysis (conclusions of analyses)}

The analysis is based on the premise that rural landscape is mostly a multifunctional biocultural landscape, the key platform for integration of biological and cultural diversity for the well-being of humans. This approach is the foundation of the SWOT analysis that identifies relationships between cultural diversity and biodiversity regarding landscape functions (Agnoletti and Rotherham 2015). The analyses suggest that the Kraków-Częstochowa Upland has an abundance of natural and landscape, historic, and traditional elements as well as biodiversity that are unique in Poland and Europe and build the environmental, tourist, and economic potential of the place and a safe harbour for cultural heritage (Table 1).

The primary threat to the upland is the lack of an effective local spatial development plan to prevent the introduction of alien architectural patterns and projects (Table 2).

Table 1 The SWOT analysis - strengths with their weighting factors

\section{Strengths}

S1 Environmental, landscape, and biodiversity abundance unique in Poland and Europe, diversified 0.3 patchwork of agricultural fields

S2 A large share of the area is protected (a national park, landscape parks) 0.2

S3 Abundant historic assets, a large number of heritage sites, well established local/regional tradi- 0.2 tions

S4 Unique tourist attractions, tourism potential (caves, limestone outliers, topography, quarries, the Błędów Desert) that are conveniently located (close to the Katowice agglomeration and Kraków agglomeration)

S5 Rich agricultural traditions related to processing, craft (a broad array) 
Table 2 The SWOT analysis — weaknesses with their weighting factors

\begin{tabular}{|c|c|c|}
\hline \multicolumn{3}{|c|}{ Weaknesses } \\
\hline W1 & Uncontrolled individual development projects, lack of an effective spatial policy & 0.3 \\
\hline W2 & $\begin{array}{l}\text { Escalation of agricultural abandonment, setting land aside, uncontrolled afforestation of land } \\
\text { through ecological succession }\end{array}$ & 0.3 \\
\hline W3 & $\begin{array}{l}\text { The course of transport network and eco-spatial fragmentation (a threat to environmental aspects } \\
\text { of the area) }\end{array}$ & 0.2 \\
\hline W4 & Scarce groundwater and undergroundwater resources & 0.1 \\
\hline W5 & Close proximity to industrial (urban) areas; air, water, and soil pollution & 0.1 \\
\hline
\end{tabular}

Additionally, the economic situation unfavourable for rural areas and a short distance to urban zones reduce the economic viability of farming, which contributes to the gradual reduction of agricultural land, increase in land set aside and under forest succession (Janus et al. 2021; Janus and Bozek 2019a, b). The effect is amplified by various measures for environmental protection that imposed limitations on selected agricultural activities.

Residents are increasingly aware of the need for the conservation of cultural heritage, landscape, natural environment, and agricultural system assets, which is apparent from numerous grassroots initiatives joined by young people (Tables 3 and 4). The awareness is further built by programmes and projects funded by the EU to preserve biodiversity, supporting initiatives to promote cultural heritage or protect areas through sustainable development (Miu et al. 2020; Hristov 2020).

Table 3 The SWOT analysis-opportunities with their weighting factors

Opportunities

O1 Improved local awareness / grassroots initiatives to protect cultural heritage

$\mathrm{O} 2$ Aid from EU programmes to preserve biodiversity and further opportunities to acquire resources/projects

O3 An opportunity to restore regional agricultural and processing traditions in situ (cultural heritage of watermills, fulling mills, or groats mills)

O4 An effort to include the area on the UNESCO World Heritage List

O5 An opportunity to establish a Globally Important Agricultural Heritage System to aid protection through development

Table 4 The SWOT analysis - threats with their weighting factors

Threats

\begin{tabular}{lll} 
T1 & Impaired economic situation, economic infeasibility & 0.2 \\
T2 & Fewer resources involved in the growth/conservation of biodiversity & 0.2 \\
T3 & Legal protection of the area resulting in limited development and active farming & 0.2 \\
T4 & A growing number of vehicles on roads in the region; increased pollution & 0.2 \\
T5 & $\begin{array}{l}\text { Small support for farmers through grants; fewer people interested in agriculture (being } \\
\text { a farmer) }\end{array}$ & 0.2 \\
\hline
\end{tabular}


An external threat could be a decreased readiness of residents to keep alive traditional farming and craft. Simultaneously, opening to active local tourism and increased pressure from active leisure in the upland threaten its resources and unique topographical features.

One should consider several key strategies when seeking answers to questions about the impact of internal and external factors and their interactions (Tables 5 and 6). Note that historical rural landscapes, especially those with significant heterogeneity, are often related to traditional practices and provide important examples to aid comprehension of biocultural diversity (Agnoletti and Rotherham 2015).

The values of the interactions between the analysis factors (Tables 7, 8 and 9) facilitate determination of one of the four development strategies (Sarsby 2016):

1. the aggressive one, when strengths and related opportunities prevail,

2. the conservative one, when strengths and related threats prevail,

3. the competitive one, when weaknesses and related opportunities prevail,

Table 5 Questions to the SWOT analysis

\begin{tabular}{lll}
\hline & Opportunities $(\mathrm{O})$ & Threats $(\mathrm{T})$ \\
\hline Strengths $(\mathrm{S})$ & $\begin{array}{c}\text { Will the strength facilitate the } \\
\text { use of a specific opportu- } \\
\text { nity? }\end{array}$ & Will the strength help eliminate a specific threat? \\
Dees the weakness limit the & $\begin{array}{c}\text { Does the weakness increase the risk associated } \\
\text { possibility of using a specific } \\
\text { opportunity? }\end{array}$ & \\
\hline
\end{tabular}

Table 6 Questions to the TOWS analysis

Table 7 Interactions between SWOT analysis factors

\begin{tabular}{lll}
\hline & Opportunities (O) & Threats (T) \\
\hline Strengths (S) & $\begin{array}{c}\text { Does the opportunity } \\
\text { reinforce a specific } \\
\text { strength? }\end{array}$ & $\begin{array}{c}\text { Does the threat } \\
\text { eliminate } \\
\text { a specific } \\
\text { strength? }\end{array}$ \\
Weaknesses (W) & $\begin{array}{l}\text { Does the opportunity } \\
\text { help eliminate a specific } \\
\text { weakness? }\end{array}$ & $\begin{array}{l}\text { Does the threat } \\
\text { emphasise } \\
\text { a specific } \\
\text { weakness? }\end{array}$ \\
& & weakn
\end{tabular}

\begin{tabular}{lllllllllll}
\hline & O1 & O2 & O3 & O4 & O5 & T1 & T2 & T3 & T4 & T5 \\
\hline S1 & 1 & 1 & 1 & 1 & 1 & 0 & 0 & 0 & 0 & 0 \\
S2 & 1 & 1 & 0 & 1 & 1 & 0 & 0 & 0 & 1 & 0 \\
S3 & 1 & 1 & 1 & 1 & 1 & 1 & 0 & 0 & 0 & 1 \\
S4 & 1 & 1 & 1 & 1 & 1 & 0 & 0 & 1 & 0 & 1 \\
S5 & 1 & 1 & 1 & 1 & 1 & 1 & 0 & 1 & 0 & 1 \\
W1 & 1 & 0 & 0 & 1 & 1 & 0 & 1 & 0 & 1 & 0 \\
W2 & 1 & 1 & 1 & 1 & 1 & 1 & 0 & 0 & 0 & 0 \\
W3 & 0 & 0 & 0 & 1 & 1 & 0 & 1 & 1 & 1 & 0 \\
W4 & 0 & 0 & 0 & 0 & 0 & 0 & 0 & 1 & 0 & 1 \\
W5 & 0 & 0 & 0 & 0 & 1 & 0 & 1 & 0 & 1 & 1 \\
\hline
\end{tabular}


Table 8 Interactions between TOWS analysis factors

\begin{tabular}{lllllllllll}
\hline & O1 & O2 & O3 & O4 & O5 & T1 & T2 & T3 & T4 & T5 \\
\hline S1 & 1 & 1 & 1 & 1 & 1 & 0 & 1 & 0 & 1 & 1 \\
S2 & 1 & 0 & 0 & 0 & 0 & 0 & 0 & 0 & 0 & 0 \\
S3 & 1 & 1 & 1 & 1 & 1 & 0 & 0 & 0 & 0 & 0 \\
S4 & 1 & 1 & 1 & 1 & 1 & 0 & 0 & 0 & 0 & 0 \\
S5 & 1 & 1 & 1 & 1 & 1 & 0 & 1 & 0 & 0 & 0 \\
W1 & 1 & 1 & 0 & 1 & 1 & 0 & 1 & 1 & 0 & 0 \\
W2 & 0 & 1 & 1 & 1 & 1 & 1 & 1 & 1 & 1 & 1 \\
W3 & 0 & 0 & 1 & 1 & 1 & 0 & 0 & 0 & 1 & 0 \\
W4 & 0 & 0 & 0 & 0 & 0 & 0 & 0 & 0 & 0 & 0 \\
W5 & 1 & 0 & 0 & 0 & 0 & 0 & 0 & 0 & 0 & 0 \\
\hline
\end{tabular}

Table 9 Results of the SWOT/TOWS analysis

\begin{tabular}{lll}
\hline & Opportunities $(\mathrm{O})$ & Threats $(\mathrm{T})$ \\
\hline Strengths (S) & Aggressive strategy & Conservative strategy \\
& Number of interactions 90 & Number of interactions 24 \\
& Weighted number of interactions 18.6 & Weighted number of interactions 4.6 \\
Weaknesses (W) & Competitive strategy & Defensive strategy \\
& Number of interactions 46 & Number of interactions 38 \\
& Weighted number of interactions 10.0 & Weighted number of interactions 8.3 \\
\hline
\end{tabular}

4. the defensive one, when weaknesses prevail and threats are associated with them.

The calculations (SWOT/TOWS analysis) indicate that the largest number of interactions, including weights, were found for strengths and opportunities. Therefore, the best strategy for the spatial development of the area is the aggressive one. The strategy is founded on strengths reinforced by opportunities. High biodiversity is often preserved in landscapes where agricultural practices retained numerous 'traditional' features. Babai et al. (2015) assessed the impact of environment protection and agricultural and environmental regulations on the preservation of selected components of traditional farming in two such cultural landscapes, in Gyimes, Romania, and Orse'g, Hungary. The unique landscape and profile of the Kraków-Częstochowa Upland can provide examples of good practices and room for collaboration between the economy and tourism, taking into account the protection of cultural heritage and environmental qualities. Nevertheless, it needs targeted support schemes, which can be based on the present SWOT analysis and in-depth cultural landscape research. It may contribute to the preservation of biological and cultural diversity in areas with traditional agricultural systems.

Targeted support schemes are support from local and central governments for concepts promoting traditional local agricultural practices, small industrial facilities (such as watermills), local household products, services promoting local craft, husbandry, or traditional production techniques for produce, including their commercialisation (Feuer et al. 2021). They can also open space for the joint effort of economy and tourism in the upland by promoting products, traditional practices, cultivation, and husbandry and cultural heritage as part of the tourist offer. 


\section{Conclusions}

Many researchers today focus on the prevention of dynamic changes in traditional landscapes and traditional agricultural systems. Such effort is necessary because many of such landscapes have been irrecoverably lost. The same applies to Poland, where the changes have accelerated after the socio-political transformation of 1989.

Diversity within landscapes and interrelations between humans and nature are most probably better standards for managing areas where human impact has long history than standards prepared for areas where anthropogenic impact was scarce (Agnoletti 2014). Many researchers indicate that complex landscape mosaics are more valuable than straightforward agrarian and forest habitats emerging from agricultural practices (Moreira and Russo 2007). Nevertheless, another approach to biodiversity is also necessary. One that would consider the profile of the landscape in an evident way to identify the complexity and fragmentation of many landscape mosaics not as degradation or threat, but an opportunity for biodiversity.

The research demonstrates the suitability of the Globally Important Agricultural Heritage System to new actions aimed at the restoration of the resilience of traditional landscapes and traditional agricultural systems to new challenges (unprecedented threats) without sacrificing their biological and cultural richness or production capabilities.

The upland has been under considerable threat in recent decades due to the decline of pasturing, intensification of agriculture, and resultant multidimensional land use changes, afforestation, clearing, and conversion into arable land. Other substantial threats are the spread of alien species and secondary succession.

The example of the investigated area (the Kraków-Częstochowa Upland) shows that it is impossible to protect and conserve valuable landscapes and agricultural and processing systems solely by imposed legal regulations, top-down measures. The area is almost entirely protected and still, the agricultural system is deteriorating and vanishing. The cause is a lack of 'human activity' 'grassroots actions', which have been inherently linked to the place for centuries. With farming abandonment and exacerbation of the economic production situation came tragic times. Implementation of a Globally Important Agricultural Heritage System (GIAHS) under an active farming system to protect the area is reasonable when residents are interested in it. Two years ago, they started an initiative to include the Kraków-Częstochowa Upland on the UNESCO World Heritage List.

As traditional and customary agricultural systems collapse, a serious threat looms over environment and heritage protection. We agree with Rotherham that it is most probably the greatest threat to environment protection in the 21st century (Agnoletti and Rotherham 2015). Moreover, such landscape transformations often have a dramatic and often severe impact on human rural communities and traditional agricultural systems.

Author contributions $\mathrm{BP}, \mathrm{JH}$ and $\mathrm{MU}$ conceived and wrote the manuscript. The authors contributed to the editorial process.

Funding This study was financed by the Ministry of Science and Higher Education of the Republic of Poland under the project "Cultural heritage of small homelands", No. PPI/APM/2018/1/00010/U/001, financed by the Polish National Agency for Academic Exchange as part of the International Academic Partnerships.

Data availability All material used is available through websites. 


\section{Declarations}

Conflict of interest There was no conflict of interest in this article.

Open Access This article is licensed under a Creative Commons Attribution 4.0 International License, which permits use, sharing, adaptation, distribution and reproduction in any medium or format, as long as you give appropriate credit to the original author(s) and the source, provide a link to the Creative Commons licence, and indicate if changes were made. The images or other third party material in this article are included in the article's Creative Commons licence, unless indicated otherwise in a credit line to the material. If material is not included in the article's Creative Commons licence and your intended use is not permitted by statutory regulation or exceeds the permitted use, you will need to obtain permission directly from the copyright holder. To view a copy of this licence, visit http://creativecommons.org/licenses/by/4.0/.

\section{References}

Agnoletti M (2014) Rural landscape, nature conservation and culture: some notes on research trends and management approaches from a (southern) European perspective. Landsc Urban Plan 126:66-73

Agnoletti M (2014) Rural landscape, nature conservation and culture: some notes on research trends and management approaches from a (southern) European perspective. Landscape and Urban Planning 126:66-73

Agnoletti M, Rotherham ID (2015) Landscape and biocultural diversity. Biodivers Conserv 24:3155-3165. https://doi.org/10.1007/s10531-015-1003-8

Agnoletti M, Emanueli F, Corrieri F, Venturi M, Santoro A (2019) Monitoring traditional rural landscapes. Case Italy Sustain 11:6107. https://doi.org/10.3390/su11216107

An C, Cai M, Guy C (2020) Rural sustainable environmental management. Sustainability 12(15):6688. https://doi.org/10.3390/su12166688

Babai D, To'th A, Szentirmai I, Biro’ M, Ma'te' A, Demeter L, Sze'pligeti M, Varga A, Molna'r A', Kun R, Molna'r Z (2015) Do conservation and agri-environmental regulations support effectively traditional small-scale farming in East-Central European cultural landscapes? Biodiv Conserv. https://doi.org/10. 1007/s10531-015-0971-z

Bogdanowski J (1997) Procesy osadnicze i przemiany architektoniczno-krajobrazowe (1939-1970). In: Osadnictwo i krajobraz, Natura i kultura w krajobrazie Jury, Kraków, pp 69-86

Bozac MG (2008) SWOT analysis and TOWS matrix-similarities and differences. Econ Res-Ekonomska Istrazivanja 21(1):19-34

Chmielewski TJ, Myga-Piątek U, Solon J (2015) Typologia aktualnych krajobrazów Polski. Przegląd Geograficzny 87(3):377-408

Daugstad K, Ronningen K, Skar B (2006) Agriculture as an upholder of cultural heritage? Conceptualizations and value judgements - A Norwegian perspective in international context. J Rural Stud 22(1):67-81

Feuer HN, Van Assche K, Hernik J, Czesak B, Różycka-Czas B (2021) Evolution of place-based governance in the management of development dilemmas: long-term learning from Małopolska, Poland. J Environ Planning Manag 64(8):1312-1330

García MA, Yagüe JL, de Nicolás VL, Díaz-Puente JM (2020) Characterization of globally important agricultural heritage systems (GIAHS) in Europe. Sustainability 12:1611. https://doi.org/10.3390/su120 41611

Gottfried O, De Clercq D, Blair E, Weng X, Wang C (2018) SWOT-AHP-TOWS analysis of private investment behavior in the Chinese biogas sector. J Clean Prod 184:632-647

Grove AT, Rackham O (2001) The nature of Mediterranean Europe. An ecological history. Yale University Press, Ehrhardt

Hristov J, Clough Y, Sahlin U, Smith HG, Stjernman M, Olsson O, Sahrbacher A, Brady MV (2020) Impacts of the EU's common agricultural policy "greening" reform on agricultural development, biodiversity, and ecosystem services. Appl Econ Perspect Policy 42(4):716-738

Janus J, Bozek P (2019) Aerial laser scanning reveals the dynamics of cropland abandonment in Poland. J Land Use Sci 14(4-6):378-396

Janus J, Bozek P (2019) Land abandonment in Poland after the collapse of socialism: over a quarter of a century of increasing tree cover on agricultural land. Ecol Eng 138:106-117 
Johann E, Agnoletti M, Axelsson AL, Bürgi M, Östlund L, Rochel X et al (2004) History of secondary spruce forests in Europe. In: Spiecker H, Hansen J, Klimo E, Skovsgaard JP, Sterba H, von Teuffel K et al (eds) Norway spruce conversion, option and consequences, vol 18. Brill Leiden, Boston, pp 25-62

Janus J, Bozek P, Mitka B, Taszakowski J, Doroz A (2021) Long-term forest cover and height changes on abandoned agricultural land: an assessment based on historical stereometric images and airborne laser scanning data. Ecol Ind 120:106904

Kohsaka R, Matsuoka H, Uchiyama Y, Rogel M (2019) Regional management and biodiversity conservation in GIAHS: text analysis of municipal strategy and tourism management. Ecosyst Health Sustain 5(1):124-132. https://doi.org/10.1080/20964129.2019.1610336

Macdonald DW et al (2020) Predicting biodiversity richness in rapidly changing landscapes: climate, low human pressure or protection as salvation? Biodivers Conserv 29:4035-4057. https://doi.org/10.1007/ s10531-020-02062-x

Moreira F, Russo D (2007) Modeling the impact of agricultural abandonment and wildfires on vertebrate diversity in Mediterranean Europe. Landsc Ecol 22:1461-1476

Poławski Z (2009) Land use changes in Poland during last two centuries. Teledetekcja Środowiska 42:69-82 (in Polish)

Pitte JR (1994) Histoire du paysage francais II. Pluriel, Paris

Pretty J et al (2009) The intersections of biological diversity and cultural diversity: towards integration. Conserv Soc 7(2):100-112

Przegon W, Bacior S, Sobolewska-Mikulska K (2017) Cartographic analysis of transformations of the spatial structure of lands of Podgorze in Krakow in Poland in the period of 1847-2016. Geodetski Vestnik 61(2):278-292

Ravetto ES, Nucera E, Lonati M, Alberto PF, Probo M (2020) The biodiversity promotion areas: effectiveness of agricultural direct payments on plant diversity conservation in the semi-natural grasslands of the Southern Swiss Alps. Biodivers Conserv 29:4155-4172. https://doi.org/10.1007/ s10531-020-02069-4

Santoro A, Venturi M, Agnoletti M (2020) Agricultural heritage systems and landscape perception among tourists. The case of Lamole, Chianti (Italy). Sustainability 12:3509. https://doi.org/10.3390/su120 93509

Sarsby A (2016) SWOT analysis: a guide to SWOT for business studies students. Leadreship Library, UK

Spielhofer R, Hunziker M, Kienast F, Hayek UW, Gret-Regamey A (2021) Does rated visual landscape quality match visual features? An analysis for renewable energy landscapes. Landsc Urban Plan 209:104000

Staszkiewicz J (1986) Betula-Szaferi - A new species of the genus Betula L from Poland. Acta Soc Bot Poloniae 55(3):361-366

UNEP (2010), What is biodiversity? https://www.unesco.pl/fileadmin/user_upload/pdf/BIODIVERSITY_ FACTSHEET.pdf . Accessed 25 May 2021

von Verschuer F (2021) Making post/anthropocentric futures in agrobiodiversity conservation. Nature Culture 16(1):47-64

Wagner HH, Wildi O, Ewald KC (2000) Additive partitioning of plant species diversity in an agricultural mosaic landscape. Landsc Ecol 15:219-227

Wartmann FM, Frick J, Kienast F, Hunziker M (2021) Factors influencing visual landscape quality perceived by the public. Results from a national survey. Landsc Urban Plan 208:104024

Weihrich H (1982) The tows matrix — a tool for situational analysis. Long Range Plan 15(2):54-66

Węcławowicz G (2002) Przestrzeń i społeczeństwo współczesnej Polski. Warszawa PWN pp 177

\section{Source documents for the study area}

Bogdanowski J (2002) Jura warowna jako "kulturowy zasób turystyczny” [In:] Zamki i przestrzeń społeczna w Europie środkowej i wschodniej. In: Antoniewicz M (ed) Instytut Historii Wyższej Szkoły Pedagogicznej w Częstochowie, Polskie Towarzystwo Heraldyczne. Wydawnictwo DiG, Warszawa, pp 497-509

Bronisz S, Pucek K, Stróżecki A (1994) Wyżyna Krakowsko-Częstochowska, Wydawnictwo kartograficzne Eko-Graf. Wrocław

Bryś H, Gołuch P (2011) Pustynia Błędowska dawniej i dziś - interpretacja wieloczasowych zdjęć lotniczych i obrazów satelitarnych. Acta Sci Pol Geodesia et Descriptio Terrarum 10(2):5-16

Etnografia Polski: przemiany kultury ludowej, vol 21981

Falniowska-Gradowska A (1995) Ojców w dziejach i legendzie. OPN, Ojców 
Michalik S (1993) Świat roślin i zwierząt Wyżyny Krakowskiej [In:] Nauka i Kultura w krajobrazie Jury, t. III Przyroda. Zarząd Zespołu Jurajskich Parków Krajobrazowych, Kraków

Miu IV, Rozylowicz L, Popescu VD, Anastasiu P (2020) Identification of areas of very high biodiversity value to achieve the EU Biodiversity Strategy for 2030 key commitments. PEERJ 8:e10067

Myczkowski Z (1997) Współczesny krajobraz osadniczy i architektura po roku 1970 [In:] Osadnictwo i krajobraz Z. Noga (ed), Natura i kultura w krajobrazie Jury, Kraków, pp 77-87

Myga-Piątek U (2004) Kompleksowe badania krajobrazowe na przykładzie Wyżyny KrakowskoCzęstochowskiej, [In:] Ecological Geography: history, theory, methods, practice. Conference Materials, 27-29 May 2004 Tarnopol, Ukraine, pp 59-69

Myga-Piątek U (2008) Krajobrazy kulturowe Wyżyny Krakowsko-Częstochowskiej. Rozważania o przyrodzie, historii, wartościach i zagrożeniach. Zarządzanie Krajobrazem Kulturowym. Prace Komisji Krajobrazu Kulturowego 10:337-357

Myga-Piątek U, Partyka J (2003) Stawy Wyżyny Krakowsko-Częstochowskiej jako ważny element krajobrazu - zarys koncepcji projektu rewitalizacji stawów [In:] Zróżnicowane przemiany środowiska przyrodniczo-kulturowego Wyżyny Krakowsko-Częstochowskiej Partyka J (ed), vol 2, Kultura, Wyd. Ojcowski Park Narodowy i in. Ojców, pp 395-402

Ogrodowska B (2004) Polskie obrzędy i zwyczaje doroczne. Warszawa: Muza SA, ISBN 83-7200-947-3

Reinfuss R (1960) Sztuka ludowa w Polsce

Sosin-Bzducha E, Chełmińska A, Sikora J (2012) Wypas owiec jako element czynnej ochrony Krajobrazu Wyżyny Krakowsko-Częstochowskiej. Wiadomości Zootechniczne, R. L 2 pp 85-88

Sroczyńska J (2018) Enhancing the Attractiveness of Architectural Monuments as Tourist Attractions: Medieval Castle Ruins in the Area of Jura Krakowsko-Czestochowska in Poland as a Case Study, 3rd World Multidisciplinary Civil Engineering, Architecture, Urban Planning Symposium (WMCAUS) Location: Prague, Czech Republic, Jun 18-22, 2018

Uruszczak M (2019) Zabytkowe ogrody rezydencjonalne Jury Krakowsko-Częstochowskiej. University of Agriculture Kraków Publishing House

Publisher's Note Springer Nature remains neutral with regard to jurisdictional claims in published maps and institutional affiliations. 